\title{
BERN RADIOCARBON DATES VII
}

\author{
H. OESCHGER, T. RIESEN, and J. C. LERMAN
}

\section{Universität Bern}

Physikalisches Institut, Sidlerstrasse 5, CH-3000 Bern, Switzerland

\section{INTRODUCTION}

This list contains a selection of dates from analyses carried out during the past few years. Samples are grouped in geologic-palynologic, and archaeologic sections according to main problem. When influence of human activity on pollen diagrams has been observed it has been explicitly indicated. The descriptions and comments have been written in collaboration with collectors and submitters. For the samples from Switzerland, general reference has also been made to Welten (1958a) and to sections on palynology, geology, and archaeology in work edited by the Schweizerische Gesellschaft für Ur- und Frühgeschichte (1968-1970).

Combustion of samples and gas counting have been done according to description in previous list (Radiocarbon, 1965, v. 7, p. 1-2). The samples were treated before combustion only with cold hydrochloric acid. No more elaborate procedure was performed. Results are expressed in conventional $\mathrm{C}^{14}$ years as defined in the Editorial Statement of Radiocarbon (w.r.t. NBS standard; $\mathrm{t}_{1 / 2}=5568$ yr; reference year A.D. 1950 $=0$ в.P.). The given standard deviations $\sigma$ (or "errors") are derived with the following formula

$$
\sigma=\sqrt{\sigma_{\mathrm{c}}^{2}+\sigma_{\mathrm{f}}^{2}}
$$

where: $\sigma_{\mathrm{c}}=$ counting statistics including estimated uncertainties in filling temperature, barometric pressure, working voltage, etc.; $\sigma_{\mathrm{f}}=$ estimated uncertainty due to isotope fractionation effects. The term $\sigma_{\mathrm{f}}$ has been included because no ${ }^{13} \mathrm{C} /{ }^{12} \mathrm{C}$ ratios have been measured on samples of present list; it was estimated to be 80 years from the observed distribution of deviations of $\delta^{13} \mathrm{C}_{\mathrm{PDB}}(\mathrm{ca} . \pm 5 \%$ ) from the "normal" value $\left(\delta^{13} \mathrm{C}_{\mathrm{PDB}}=-25.0 \%\right)$ in wood, peat, gyttja and charcoal from European localities (Radiocarbon, v. 9, 1967, p. 113-144; v. 11, 1969, p. 519-539) considered valid only for materials derived from plants with Calvin photosynthetic cycle. The formula is not valid for materials related to plants with Slack-Hatch cycle (and lack of photorespiration) and CAM (Crassulacean Acid Metabolism) as pointed out by Lerman (ms. in prep.); in such a case the age must be increased in about $(240 \pm 20)$ yr (Lerman, 1970, p. 104-105; Radiocarbon, 1969, v. 11, p. 351, 369, 378-383). The original counting standard deviation $\left(\sigma_{\mathrm{c}}\right)$ can be retrieved from the given $\sigma$ by:

$$
\sigma_{\mathrm{c}}=\sqrt{\sigma^{2}-640} \quad \text { (in years) }
$$

When considered interesting, the dates have been corrected for secular variations by means of the calibration curve suggested by Suess (1970). The derived calendar dates for the interval $\pm 1 \sigma$ are given in 
the comments to the dates. Analysis numbers between B-1001 and B-2000 have been reserved for ice dating (Radiocarbon, 1967, v. 9, p. 28).

\section{ACKNOWLEDGMENTS}

We thank all those who have helped in the present dating, especially to F. Kaspar for assisting in the measurements, and to M. Welten and H.-G. Bandi for advice in the selection of the samples. The laboratory is financed by the Schweizerischer Nationalfonds.

\section{GEOLOGIC-PALYNOLOGIC SAMPLES}

\section{A. Switzerland}

\section{Ballmoos series, Appenzell, Switzerland}

Sec. in bog of Ballmoos ( $47^{\circ} 22^{\prime} \mathrm{N}$ Lat, $9^{\circ} 30^{\prime} \mathrm{E}$ Long) alt $950 \mathrm{~m}$, near Stoss pass, between Altstätten and Gais, Appenzell Ausserrhoden, Switzerland. Investigated within general program of phytopaleontologic and paleoclimatic studies in NE Switzerland. Core $8.5 \mathrm{~m}$ long taken with Hiller borer. Coll. 1959 and subm. by P. Wegmüller and M. Welten, Syst.Geobot. Inst., Univ. Bern, Switzerland.

\section{B-958. Ballmoos, $120 \mathrm{~cm}$}

$3680 \pm 190$

Sphagnum peat from 110 to $130 \mathrm{~cm}$ depth.

\section{B-957. Ballmoos, $190 \mathrm{~cm}$}

1730 B.C.

Sphagnum peat from 180 to $200 \mathrm{~cm}$ depth.

$6000 \pm 100$

B-956. Ballmoos, $370 \mathrm{~cm}$

4050 B.c. depth.

Telmatic peat (Phragmites and Magnocarices) from 360 to $380 \mathrm{~cm}$

\section{B-955. Ballmoos, $515 \mathrm{~cm}$}

$9330 \pm 130$

Gyttja from 505 to $525 \mathrm{~cm}$ depth.

7380 B.c.

B-954. Ballmoos, $535 \mathrm{~cm}$

$10,060 \pm 130$

Gyttja from 525 to $545 \mathrm{~cm}$ depth.

8110 B.C.

\section{B-953. Ballmoos, $625 \mathrm{~cm}$}

$7460 \pm 120$

$\mathbf{5 5 1 0}$ в.C.

Gyttja from 610 to $640 \mathrm{~cm}$ depth, contained some mineral sediments. Comment: material clearly dates palynologically from Aller $\phi \mathrm{d}$ and shows no evidence of younger intrusions. Discrepancy of $\mathrm{C}^{14}$-date is not understood.

General Comment (M. Welten, written commun., 1970): dates form very consistent series from end of Younger Dryas to Sub-Boreal. Abies invaded mixed oak forest at ca. 6500 B.P. Relatively late date of upper layers fully agrees with fact that several $\mathrm{m}$ of upper stratum of Sphagnum peat have been cut away in modern times. 


\section{Oberaar series, Bern, Switzerland}

Two secs. at end moraine of Oberaar Glacier $\left(46^{\circ} 32^{\prime} 52^{\prime \prime} \mathrm{N}\right.$ Lat, $8^{\circ} 15^{\prime} 23^{\prime \prime}$ E Long), alt $2320 \mathrm{~m}$, on $\mathrm{S}$ slope of Zinggenstock Mt., W of Grimsel pass, near Guttannen, canton Bern, Switzerland, ca. $500 \mathrm{~m}$ above present timber line; recent vegetation ranges from very young pioneer plant communities to consolidated alpine meadows. Purposes of investigation were, (1) to study vegetational history above timber line in Bernese Oberland region by means of pollen analyses in soil profiles, (2) to date moraines of Oberaar Glacier.

Pollen profiles analyzed and interpreted by K. Ammann (ms. in preparation). Coll. 1967 and subm. by K. Ammann, Syst.- Geobot. Inst., Univ. Bern, Switzerland.

\section{B-906. Oberaar A}

$270 \pm 90$

Sandy terrestrial peat from $195 \mathrm{~cm}$ depth in transect (G II) at middle of $\mathrm{S}$ side of end moraine. Comment: compare with B-254 (Radiocarbon, 1961, v. 3, p. 19): $4600 \pm 80$ B.P. from wood found after dredging at 4 to $5 \mathrm{~m}$ depth inside same moraine (now below water level of storage lake) 100 to $200 \mathrm{~m} \mathrm{~S}$ of present transect (according to A. Minning, oral commun.). Thus both depth and age difference of samples indicate earlier death for B-254 than glacier advance dated by present sample. Calendar date estimated from calibration curve (see Introduction) is between A.D. 1450 and A.D. 1740. To attempt more precise dating of moraine, succession of several samples would be necessary due to wriggles in curve.

\section{B-908. Oberaar I}

$5100 \pm 130$

Slightly foliated terrestrial peat in upper part of stratum, from 22 to $23 \mathrm{~cm}$ depth, in Cut GI, at $13 \mathrm{~m}$ outside end moraine. High content of Cyperaceae $(60 \%)$, low content of Gramineae $(20 \%)$, and high amounts of herbaceous pollen, indicate warm climate. Considered end of Atlantic.

\section{B-907. Oberaar B}

$6300 \pm 100$

Slightly foliated terrestrial peat from 26 to $28 \mathrm{~cm}$ depth in central part of stratum in Cut GI, at $7 \mathrm{~m}$ outside end moraine, at ca. $6 \mathrm{~m}$ $S$ of sample Oberaar I, with same pollen content (see above). Comment: calculated sedimentation rate averages ca. $0.5 \mathrm{~cm} / 100 \mathrm{yr}$.

General Comment: last 2 dates show that well-developed alpine meadows vegetation existed at $2300 \mathrm{~m}$ alt in Bernese Oberland region at end of Atlantic period. Other soil profiles in Swiss Alps have been studied earlier by Welten (1958b).

\section{Hängstli series, Bern, Switzerland}

Sec. in raised bog near Hängstli (46 $47^{\prime} 5^{\prime \prime} \mathrm{N}$ Lat, $7^{\circ} 50^{\prime} 0^{\prime \prime}$ E Long), alt $1260 \mathrm{~m}$, near Eriz, $17 \mathrm{~km}$ E of Thun, canton Bern, Switzerland. Core 
$4.6 \mathrm{~m}$ long taken with Hiller borer for pollenanalytical study of vegetational development in transition zone from montane to sub-alpine belts (K. Heeb, ms. in preparation). Coll. 1967 and subm. by K. Heeb, Syst.Geobot. Inst., Univ. Bern, Switzerland.

\section{B-927. Hängstli, $75-100 \mathrm{~cm}$}

$1960 \pm 110$

10 B.c.

Sphagnum peat from 75 to $100 \mathrm{~cm}$ depth. Picea dominant. Fagus increase (Sub-Atlantic). Appearance of cereals pollen. Comment: forest composition similar to present. From correction of $\mathrm{C}^{14}$ secular variations by means of calibration curve (see Introduction), calendar age is 130 B.C. to A.D. 100 .

\section{B-928. Hängstli, $315 \mathrm{~cm}$}

$4860 \pm 110$

Sphagnum peat from $315 \mathrm{~cm}$ depth. From 290 to $330 \mathrm{~cm}$ immigration of Picea which competes with Abies. Mixed oak forest with Quercus dominance. Comment: pollen spectrum shows transition to more continental climate at beginning of Sub-Boreal.

\section{B-929. Hängstli, $390 \mathrm{~cm}$}

$5920 \pm 130$ 3970 B.C.

Cyperaceous peat from $390 \mathrm{~cm}$ depth. From 370 to $440 \mathrm{~cm}$, immigration of Abies alba, dominating later; mixed oak forest and Corylus decrease. Comment: transition from Boreal to Atlantic.

General Comment: profile shows typical development for alt, consisting in change of Abies to Picea forest. Correlates in general with sec. at Wachseldorn (this list) where immigration of Picea is synchronous. Peat sedimentation did not begin before Atlantic; mean calculated peat growth rate is ca. $8 \mathrm{~cm} / 100 \mathrm{yr}$. Cereal pollen indicate human activity in historical times.

\section{Wachseldorn series, Bern, Switzerland}

Two secs. in Untermoos raised bog in Wachseldorn $\left(46^{\circ} 49^{\prime} 15^{\prime \prime}\right.$ $\mathrm{N}$ Lat, $7^{\circ} 44^{\prime} 5^{\prime \prime} \mathrm{E}$ Long), $980 \mathrm{~m}$ alt, $11 \mathrm{~km} \mathrm{E}$ of Thun, Aare valley, canton Bern, Switzerland. Taken to study Late Glacial vegetational history. Present dates continue previously pub. series (Radiocarbon, 1967, v. 9, p. 30-31); samples named Wachseldorn are from same cut $(545 \mathrm{~cm}$ length) in peat wall of mentioned series. Sample B-962, Untermoos, is from cut in peat wall at $170 \mathrm{~m}$ ESE from previous cut, and belongs to same bog. Thickness of samples, in general, ca. $2 \mathrm{~cm}$.

Aare glacier covered $\mathrm{E}$ region up to ca. $1000 \mathrm{~m}$ alt. This combined with high precipitation made growth of raised bogs possible. Special vegetational conditions observed in locality are, (1) very early beginning of peat growth, (2) exceptionally fast peat growth during Pre-Boreal, (3) exceptional composition of pollen during Late Glacial with dominance of Cyperaceae and lack of Betula, possibly due to poor soils of Molasse substratum. 
Pollenanalytically investigated by K. Heeb (ms. in preparation). Coll. 1965 by M. Welten and K. Heeb; subm. by M. Welten.

\section{B-692. Untermoos, $150 \mathrm{~cm}$}

Sphagnum peat from $150 \mathrm{~cm}$ depth. Comment: despite immigration of Picea, dominance of Abies (Sub-Boreal). Mixed oak forest pollen from lower alts is present (mainly Quercus, due to decrease of Ulmus, Fraxinus, and Tilia).

\section{B-924. Wachseldorn, $225 \mathrm{~cm}$}

$6690 \pm 100$

Sphagnum peat from $225 \mathrm{~cm}$ depth. Comment: pollen spectrum from 200 to $230 \mathrm{~cm}$ depth shows: decrease of Corylus and mixed oak forest pollen, latter due to Ulmus decrease; Abies increase (Atlantic). Change of mixed oak forest to Abies forest due to wetter climate of period.

\section{B-2011. Wachseldorn, $330 \mathrm{~cm}$}

$8950 \pm 110$

Cyperaceous peat from $330 \mathrm{~cm}$ depth. Comment: pine pollen dominant but decreasing, simultaneous increase of Cyperaceae, sharp increase of Corylus and mixed oak forest pollen.

B-2012. Wachseldorn, $358 \mathrm{~cm}$

$9680 \pm 130$

Cyperaceous peat from $358 \mathrm{~cm}$ depth. See comment to B-926 (below).

\section{B-2013. Wachseldorn, $365 \mathrm{~cm}$}

$9400 \pm 130$

Cyperaceous peat from $365 \mathrm{~cm}$ depth. See comment to B-926 (below).

\section{B-925. Wachseldorn, $387.5 \mathrm{~cm}$}

$9250 \pm 120$

7300 в.с. (below).

Cyperaceous peat from 385 to $390 \mathrm{~cm}$ depth. See comment to B-926

\section{B-926. Wachseldorn, $403.5 \mathrm{~cm}$}

$9880 \pm 120$ 7930 B.c.

Cyperaceous peat from 402 to $405 \mathrm{~cm}$ depth. Comment: at $345 \mathrm{~cm}$ appear 1st signs of mixed oak forest. In all 4 previous samples pine pollen is dominant, with decrease (from $85 \%$ to $48 \%$ ) between 360 and 400 $\mathrm{cm}$ and simultaneous increase of Cyperaceae. Due to extraordinarily rapid peat growth during this period (Pre-Boreal) change in pine pollen indicates climatic deterioration not usually found in other profiles; direct comparison of this deterioration with that of Piottino (Zoller, 1968) cannot be done because of lack of evidence (Lang, 1952). Similar but stronger $(75 \%$ to $30 \%)$ decrease in pine with simultaneous increase of Cyperaceae (and heliophile plants as Selaginella, Artemisia, and Salix) between 410 and $430 \mathrm{~cm}$ indicate Younger Dryas. Compare Samples B-700: 
$10,320 \pm 150$ B.P. for $416 \mathrm{~cm}$, and B-701: 10,550 \pm 150 B.P. for $421 \mathrm{~cm}$ depth in same profile (Radiocarbon, 1967, v. 9, p. 31).

\section{B-921. Wachseldorn, $430 \mathrm{~cm}$}

$10,130 \pm 110$

Cyperaceous peat from $430 \mathrm{~cm}$ depth. Comment: compare with B-702: 10,980 \pm 200 в.P. from $451 \mathrm{~cm}$ depth in same profile (Radiocarbon, 1967, v. 9, p. 31). From 430 to $465 \mathrm{~cm}$, dominance of pine $(65 \%)$ and few Juniperus, Salix, and Artemisia indicate Aller $\phi$ d pine forest. Deeper layers indicate weak pine increase with much Cyperaceae $(60 \%)$ and less Juniperus and Betula, suggesting bad climate of Older Dryas. Compare with B-703: $11,660 \pm 150$ B.P. from $466 \mathrm{~cm}$; B-704: 11,810 \pm 150 B.P. from $470 \mathrm{~cm}$ depth in same profile (Radiocarbon, 1967, v. 9, p. 31). At $479 \mathrm{~cm}$ depth Betula nana maximum (9\%) and decrease of Cyperaceae. At $487.5 \mathrm{~cm}$ depth, pine pollen is rare and maximum of Juniperus $(64 \%)$ indicates beginning of reforestation after retreat of glaciers (assumed to be B $\phi$ lling). Compare with B-705: 12,345 \pm 150 , from $479 \mathrm{~cm}$; B-706: 12,210 \pm 150 , from $481 \mathrm{~cm}$; B-707: $12,395 \pm 130$, from $489 \mathrm{~cm}$; B-708: 12,500 \pm 150 B.P., from $491 \mathrm{~cm}$ depth in same profile (Radiocarbon, 1967, v. 9, p. 31). At $505 \mathrm{~cm}$ depth, Cyperaceae dominates $(85 \%)$ and traces of Juniperus and pine pollen are found, showing lack of forest; considered transition Oldest Dryas/B $\phi$ lling, dated as B-709: 12,915 \pm 130 в.P. (Radiocarbon, 1967, v. 9, p. 31).

General Comment: profile shows very marked minerogenous sedimentation, due to local conditions present only during deterioration of climate in Pre-Boreal (365 to $380 \mathrm{~cm}$ depth), Younger Dryas $(415$ to $430 \mathrm{~cm}$ ), and Older Dryas (465 to $475 \mathrm{~cm}$ ). Calculated mean sedimentation rates are $6.5 \mathrm{~cm} / 100 \mathrm{yr}$, from 12,900 to ca. 9500 B.P. and $4.7 \mathrm{~cm} / 100 \mathrm{yr}$, from ca. 9300 to 6700 B.P. Dates B-2012, B-2013, and B-925 are explained, within statistics, by a possible faster organic sedimentation between ca. 9500 and ca. 9300 B.P.

\section{Seeliswald series, Bern, Switzerland}

Sec. in raised bog at Seeliswald ( $46^{\circ} 42^{\prime} 19^{\prime \prime} \mathrm{N}$ Lat, $7^{\circ} 36^{\prime} 0^{\prime \prime} \mathrm{E}$ Long), $618 \mathrm{~m}$ alt, near Reutigen, canton Bern, Switzerland. Purpose of investigation was to date beginning of organic sedimentation. General stratigraphy shows change from Cyperaceous (Phragmites and Carex) peat in lower strata to Sphagnum peat in upper strata. Bog is underlain by clay and sand. Four cores taken with Hiller borer for vegetational studies by W. Strasser (ms. in preparation). Coll. 1968 by W. Strasser, Schönauweg 17a, Steffisburg, Switzerland; subm. by M. Welten.

B.910. Seeliswald 2-535

$2900 \pm 90$

Sphagnum peat from 530 to $540 \mathrm{~cm}$ depth in Core 2.

950 B.c. 
B-911. Seeliswald 2-555

$2900 \pm 90$

Sphagnum peat from 550 to $560 \mathrm{~cm}$ depth in Core 2 .

B-912. Seeliswald 3-430

$2940 \pm 90$

990 B.C.

Sphagnum peat from 430 to $440 \mathrm{~cm}$ depth in Core 3 .

\section{B-913. Seeliswald 3-470}

$3000 \pm 100$

1050 B.c.

Sphagnum peat from 470 to $480 \mathrm{~cm}$ depth in Core 3 .

\section{B-914. Seeliswald 4-575}

$3030 \pm 130$

1080 B.c.

Sphagnum peat from 570 to $580 \mathrm{~cm}$ depth in Core 4 .

B-915. Seeliswald 5-130

$2160 \pm 100$

210 B.c.

Sphagnum peat from 125 to $135 \mathrm{~cm}$ depth in Core 5, taken ca. 150 $\mathrm{m} \mathrm{N}$ from Borings 1 to 4 .

General Comment: beginning of young bog is dated ca. 3000 B.P. when rock slide from Moosfluh Mt. blocked Reutigen valley allowing growth of peat behind rock barrier. Younger age of Sample 5-130 is explained by later inundation of $\mathrm{N}$ locality.

\section{Faninpass series, Graubünden, Switzerland}

Sec. in bog at Faninpass ( $46^{\circ} 51^{\prime} \mathrm{N}$ Lat, $9^{\circ} 44^{\prime} \mathrm{E}$ Long), alt $2212 \mathrm{~m}$, between Prättigau and Schanfigg, near Peist, Graubünden (Grisons), Switzerland. Investigated within general program of phytopaleontologic and paleoclimatic studies in NE Switzerland. Core, $260 \mathrm{~cm}$ long, taken by Hiller borer. Coll. 1960 and subm. by P. Wegmüller.

B-901. Faninpass, $118 \mathrm{~cm}$

Sphagnum peat from 105 to $130 \mathrm{~cm}$ depth.

B-902. Faninpass, $168 \mathrm{~cm}$

Sphagnum peat from 155 to $180 \mathrm{~cm}$ depth.

B-903. Faninpass, $190 \mathrm{~cm}$

Sphagnum peat from 180 to $200 \mathrm{~cm}$ depth.

B-904. Faninpass, $218 \mathrm{~cm}$

Sphagnum peat from 205 to $230 \mathrm{~cm}$ depth.
$4740 \pm 100$

2790 B.C.

$5740 \pm 100$ 3790 B.c.

$6230 \pm 130$

4280 B.C.

$7300 \pm 110$ 5350 в.c. 
B-905. Faninpass, $240 \mathrm{~cm}$

Sphagnum peat and gyttja from 230 to $250 \mathrm{~cm}$ depth.

General Comment (M. Welten): series dates most detailed of 3 profiles and pollen diagrams between Prättigau and Schanfigg. Organic sedimentation began between 9000 and 8000 B.P. Invasion of Picea took place ca. 7000 в.P. Younger peat layers seem absent.

\section{St. Moritz series, Graubünden, Switzerland}

Sec. S of Lake of St. Moritz (46 29' $17^{\prime \prime}$ N Lat, $9^{\circ} 50^{\prime} 29^{\prime \prime}$ E Long), at ca. $1770 \mathrm{~m}$ alt, Graubünden (Grisons), Switzerland. Two borings $30 \mathrm{~m}$ long in sediments of fluvio-glacial origin. Purpose of investigation was dating glacier advance (H. Zoller, ms. in prep.); succession of pollen horizons appears disturbed ( $\mathrm{H}$. Zoller, 1968, written commun.). Coll. 1966 by C. Schindler, Geotechn. Büro von Moos, Zürich, Switzerland; subm. by H. Zoller, Bot. Inst., Univ. of Basle, Switzerland.

\section{B-875. St. Moritz 1-220}

$5600 \pm 120$

Peat and silt from $220 \mathrm{~cm}$ depth in Boring 1. Picea dominance, increase of Alnus viridis.

\section{B-876. St. Moritz 1-250}

$3660 \pm 150$

1710 в.c.

Peat and silt from $250 \mathrm{~cm}$ depth in Boring 1. Pinus dominance, rich in NAP.

\section{B-877. St. Moritz 2-247}

$4450 \pm 200$

Peat and silt from $247 \mathrm{~cm}$ depth in Boring 2. Picea dominance, rich in Alnus viridis.

General Comment: first and last samples date appearance of Alnus viridis in locality at 5500 to 5000 B.P., as usual in Swiss profiles. Second date seems too young and is not accepted by submitter. Dates show ca. $25 \mathrm{~m}$ river sediments accumulated in High Engadin valley during last 5000 yr.

\section{Suossa series, Graubünden, Switzerland}

Sec. in Suossa $\left(46^{\circ} 26^{\prime} 36^{\prime \prime} \mathrm{N}\right.$ Lat, $9^{\circ} 12^{\prime} 10^{\prime \prime} \mathrm{E}$ Long) $\mathrm{S}$ of San Bernardino pass at ca. $1700 \mathrm{~m}$ alt, near San Bernardino, Graubünden, Switzerland. Studied for pollen analysis, profile gives good general view of Late Glacial climatic changes. Samples obtained by adding material from several analyzed cores. Coll. 1967 and subm. by H. Zoller.

\section{B-868. Suossa I}

$6400 \pm 100$

Bryophytic peat from 520 to $523 \mathrm{~cm}$ depth in Cores 3-6. Begins Picea dominance (Atlanticum). 


\section{B-869. Suossa II}

Bryophytic peat from 568 to $570 \mathrm{~cm}$ depth in Cores 1, 2, 3, and 5 . Abies maximum, immigration of Picea (transition Older/Younger Atlantic).

\section{B-870. Suossa III}

$8030 \pm 250$

Bryophytic peat from 715 to $718 \mathrm{~cm}$ in depth in Cores 1-4. Presence of Abies, increase of Acer and Fraxinus (Boreal).

\section{B-871. Suossa IV}

$10,430 \pm 250$

8480 в.c.

Clay gyttja with some sand from 905 to $910 \mathrm{~cm}$ depth in Cores I, K-N. Increase of Betula (end of Younger Dryas).

\section{B-872. Suossa V}

$11,300 \pm 250$

Sandy clay gyttja from 921 to $926 \mathrm{~cm}$ depth in Cores I, K-N. Pioneer phase of Aller $\phi \mathrm{d}$ with much Pinus. Underlain by sediments rich in NAP (Older Dryas).

\section{B-873. Suossa VI}

$$
11,600 \pm 200
$$

\section{B-873a. Suossa VIa}

$10,960 \pm 200$ 9010 B.c.

Sandy clay gyttja from 931 to $936 \mathrm{~cm}$ depth in Cores B-F and H. Comment: both Samples VI and VIa, from same horizon, agree within statistics but seem young according to pollen analysis which indicates pioneer phase of Older Dryas with much NAP.

\section{B-874. Suossa VII}

$13,010 \pm 200$ 11,060 в.c.

Clayey gyttja from 943 to $948 \mathrm{~cm}$ depth in Cores A-H. Pioneer phase of B $\phi$ lling with Pinus pollen underlain by sediments without pollen.

General Comment: dates show general early retreat of glaciers S of Alps and prove (1) retreat of branch of Rhine glacier from San Bernardino pass before B $\phi$ lling, (2) San Bernardino basin free of glacier ice since B $\phi$ lling.

Forest appeared at locality at end of Younger Dryas. Compared with dates (H-unpub.) from lower localities at same region as Pian di Signano (Zoller, 1960) it is concluded that Picea abies immigrated from $\mathbf{N}$ into Misox valley (Ticino) across San Bernardino pass. Calculated mean sedimentation rate is ca. $8.3 \mathrm{~cm} / 100 \mathrm{yr}$.

\section{Gola di Lago series, Ticino, Switzerland}

Sec. in Gola di Lago bog (46 $6^{\prime} 13^{\prime \prime} \mathrm{N}$ Lat, $8^{\circ} 58^{\prime} 3^{\prime \prime} \mathrm{E}$ Long), ca. $970 \mathrm{~m}$ alt in pass between Isone and Cassarate valleys, (Camignolo) near Tesserete, Ticino (Tessin), Switzerland. Studied to compare vegeta- 
tional development $\mathrm{S}$ and $\mathrm{N}$ of Alps since Late Glacial. Samples obtained by adding material from several analyzed cores $4.5 \mathrm{~m}$ long, taken with Dachnowsky sonde. Preliminary description of pollen profile, interpretation and discussion of Post-Atlantic part, by Zoller and Kleiber (1967). Coll. 1966 and subm. by H. Zoller.

B-800. Gola di Lago IV

$4420 \pm 120$

Sandy-clayey gyttja from 145 to $150 \mathrm{~cm}$ depth. 1st distinct increase of Fagus silvatica (Sub-Boreal).

\section{B-799a. Gola di Lago IIIa}

$12,580 \pm 90$

Cilay gyttja from 360 to $370 \mathrm{~cm}$ depth. Comment: strong Pinus increase interpreted as middle of Pre-Boreal. $\mathrm{C}^{14}$ result seems 2000 to 3000 yr older than expected from pollen analysis.

\section{B-798. Gola di Lago II}

$12,330 \pm 200$ Dryas).

Clay gyttja from 385 to $388 \mathrm{~cm}$ depth. Strong Betula increase (Older

\section{B-797. Gola di Lago I}

$12,610 \pm 200$

Sand and clay gyttja from 389 to $393 \mathrm{~cm}$ depth. Poor AP (>60\% NAP) with brief increase of Betula pollen (B $\phi$ lling).

General Comment: dates of deepest samples (I and II) show, (1) retreat of Ticino (Tessin) glacier into Lugano basin before B $\phi$ lling, (2) appearance of forest ca. 12,000 B.P. (Aller $\phi \mathrm{d}$ ), compare Lago Origlio series (Zoller, 1960, p. 76; Radiocarbon, 1961, v. 3, p. 17); (3) importance of Larix during pioneer phases.

Upper sample dates delayed appearance of Fagus in Ticino (Zoller and Kleiber, 1967) compared with profile at same lat in Italy, Lago di Ledro (Beug, 1964), but synchronous with that at $\mathrm{N}$ of Alps (Wegmüller, 1966). Forests with Fagus at $\mathrm{N}$ of Alps formed $1000 \mathrm{yr}$ earlier than at Ticino. Time discrepancy in extension of Abies and Fagus is $2000 \mathrm{yr}$ in Lago di Garda and $5000 \mathrm{yr}$ in Ticino. Delay of Fagus is thought to be caused by Abies occupation of forest belt. Calculated average sedimentation rate is ca. $3 \mathrm{~cm} / 100 \mathrm{yr}$.

\section{Boniger See series, Valais, Switzerland}

Several secs. from lake of Bonig (Boniger- or Böhnig-See) $\left(46^{\circ} 15^{\prime}\right.$ 33" N Lat, $7^{\circ} 50^{\prime} 35^{\prime \prime} \mathrm{E}$ Long), at $2095 \mathrm{~m}$ alt, near Törbel, Visp valley, Valais (Wallis), Switzerland. Swampy lake of Bonig lies on Moosalp terrace at ca. $10 \mathrm{~km} \mathrm{NW}$ of Grächen, driest place in Switzerland $(50 \mathrm{~cm}$ annual precipitation), near present timber-line with Pinus cembra and Larix. Staub (1927) considered Moosalp terrace to be pre-glacial valley bottom. Present lake originates from dead ice left by retreat of Visp glacier which overflowed terrace up to $2200 \mathrm{~m}$ alt in N slope of Augst- 
bordhorn Mt. Cores taken with Hiller borer. Description of present and former vegetation, and palynologic interpretations pub. by Markgraf (1969). Coll. 1965-66 and subm. by V. Markgraf, Syst.-Geobot. Inst., Univ. Bern, Switzerland, and M. Welten.

a) Late and Post Glacial vegetational history

\section{B-785. Boniger See 1-485}

Detritus gyttja with leaves of Larix and Pinus (id. by V. Markgraf) from Core 1 at 460 to $500 \mathrm{~cm}$ depth. Core 1 is $614 \mathrm{~cm}$ long reaching oldest sediments of site; from inner margin of swampy island. Comment: dates immigration of Abies alba in Valais, generally accepted as 6000 в.P. for that area (Welten, 1958a).

\section{B-787. Boniger See 4-169}

$4460 \pm 100$ 2510 B.C.

Peat with Sphagnum and Drepanocladus from Core 4 at 150 to 180 $\mathrm{cm}$ depth. Picea increase. Core 4 is $210 \mathrm{~cm}$ long, from $\mathrm{S}$ shore which is usually dry in late summer. Comment: considered to be transition Younger Atlantic/Sub-Boreal.

\section{B-788. Boniger See 4-189}

$7140 \pm 120$ 5190 B.C.

Peat with Sphagnum and Drepanocladus from Core 4 at 180 to 200 $\mathrm{cm}$ depth. Pollen shows Abies maximum of Atlantic period. Comment: compared with overlying sample (4-169, see above) hiatus of nearly 3000 $\mathrm{yr}$ is seen, probably due to disturbing effect of dead ice as late as Atlantic time. Date pub. in description of sec. must be altered.

\section{B-784. Boniger See 1-545}

$7990 \pm 110$

Algae gyttja with Pediastrum and some clay from Core 1 at 525 to $550 \mathrm{~cm}$ depth. Increase of mixed oak forest, Corylus and Betula, decrease of Pinus cembra pollen. Comment: pollen spectrum indicates slightly wetter but warm climate (transition Boreal/Older Atlantic). In Central Europe, usually dated to 7500 B.P. among others by Wegmüller (1966) and Zoller (1968), but in N Europe to 8200 в.P. (Nilsson, 1964) in agreement with present date.

\section{B-782. Boniger See 1-597}

$10,430 \pm 150$ 8480 B.C.

Algal gyttja with clay and some Pediastrum from Core 1 at 591 to $620 \mathrm{~cm}$ depth. Decrease of Betula, increase of Pinus cembra, Chenopodiaceae, and Ephedra pollen. Comment: pollen analysis indicates younger and drier part of Younger Dryas.

General Comment (Markgraf): samples date development of vegetation belts for area: during Aller $\phi$ d, timber-line with Betula and Pinus cembra was between 1800 and $2000 \mathrm{~m}$, concluded from present growth of Juni- 
perus shrubs and alpine meadow plants at $2200 \mathrm{~m}$ alt; in Younger Dryas time, timber line was pushed further downwards and steppe-like vegetation expanded; timber line returned to that altitude in Pre-Boreal time, indicated by presence of pollen of rich, tall herb vegetation (Heracleum sphondylium, Geranium sp., Chaerophyllum hirsutum, etc.) at $2200 \mathrm{~m}$; during Boreal, Larix immigrated into area and since then formed forest in sub-alpine zone together with Pinus cembra, accompanied by Abies since 6000 B.P. Subsequent development was influenced by man (see $c$, below).

b) Peat development and sedimentation rate

\section{B-846. Boniger See 2-180}

$2700 \pm 150$

Wet peat with leaves of Drepanocladus and Sphagnum from Core 2 at 170 to $190 \mathrm{~cm}$ depth. Core 2, $570 \mathrm{~cm}$ long, from $50 \mathrm{~m} \mathrm{E}$ of Core 1 , on E margin of floating island. Pollen analysis shows general tree pollen (AP) decrease at every vegetation belt; herb pollen (NAP) increase, especially cultural indicators (cereals, Plantago, Cannabis); and appearance of Juglans pollen. Comment: analyses interpreted as dating transition Sub-Boreal/Sub-Atlantic, generally 2600 B.P.

\section{B-847. Boniger See 2-250}

$3230 \pm 120$

Peat with Sphagnum and some Drepanocladus and Cyperaceae rootlets from Core 2 at 230 to $295 \mathrm{~cm}$ depth. Dominance of Pinus cembra with more Picea and less Abies than in Sample 2-350 (see below). Comment: interpreted as older part of Sub-Boreal. Relatively fast peat growthrate of $13 \mathrm{~cm} / 100 \mathrm{yr}$ (3200 to 2700 B.P.) was caused by high water level of lake.

\section{B-848. Boniger See 2-350}

$4840 \pm 120$

Peat with Sphagnum, Drepanocladus, and fungal hyphae from Core 2 at 320 to $375 \mathrm{~m}$ depth. End of Abies expansion in Pinus cembra forest at $2200 \mathrm{~m}$ alt. Appearance of Picea and agricultural indicators. Comment: considered transition Younger Atlantic/Sub-Boreal. Calculated peat growth-rate, $6 \mathrm{~cm} / 100 \mathrm{yr}$ (4800 to 3200 B.P.).

$5715 \pm 120$

B-849. Boniger See 2-435

3765 B.c.

Detritus gyttja with leaves of Larix and Pinus from Core 2 at 425 to $450 \mathrm{~cm}$ depth. Oldest Abies maximum in Pinus cembra forest. First traces of Fagus. Comment: calculated sedimentation rate during Younger Atlantic, $10 \mathrm{~cm} / 100 \mathrm{yr}$ (5700 to 4800 B.P.).

\section{B-850. Boniger See 2-490}

$7600 \pm 150$

Algal gyttja from Core 2 at 475 to $500 \mathrm{~cm}$ depth. Immigration of Abies in Rhône valley. Pollen shows well developed tall herb vegeta- 
tion (Adenostyles alliariae, Lilium martagon, Heracleum sphondylium, etc.) in Pinus cembra-Larix forest of sub-alpine zone. Comment: sedimentation rate during younger part of Older Atlantic at transition from gyttja to peat, $3 \mathrm{~cm} / 100 \mathrm{yr}$ (7600 to 5700 B.P.).

\section{B-851/2. Boniger See 2-522}

$8370 \pm 150$

Algal gyttja with Pediastrum from Core 2 at 505 to $550 \mathrm{~cm}$ depth. Decrease of Betula and Corylus, increase of Pinus and mixed oak forest pollen. Comment: considered transition Boreal/Older Atlantic. Sedimentation rate during Older Atlantic, $4.5 \mathrm{~cm} / 100 \mathrm{yr}$ (8300 to 7600 B.P.). Date pub. in description of sec. must be altered.

General Comment: sedimentation rate in lake, of different organic materials, varies, ca. $3 \mathrm{~cm} / 100 \mathrm{yr}$ during Older Atlantic, $10 \mathrm{~cm} / 100 \mathrm{yr}$ during Younger Atlantic, and $14 \mathrm{~cm} / 100$ yr during Sub-Boreal. Development of lake vegetation started late (Markgraf, 1969) ca. Atlantic time, probably delayed by influence of dead ice in bottom of lake causing sedimentation disturbances. At beginning of Older Atlantic, dense Potamogeton alpinus layer with Menyanthes and Sparganium covered lake, forming rhizome networks able to collect mud. At beginning of Younger Atlantic time, peat growth started on that layer with Drepanocladus moss later followed by Sphagnum sp. Up to beginning of Sub-Atlantic, peat growth expanded over lake. Then organic development stopped, probably due to sudden rise of water level. Only central part of peat layer could then lift and start to grow again forming floating island.

c) Human influence on vegetation

\section{B-791. Boniger See 3-30, charcoal}

B-794. Boniger See 3-30, soil with charcoal $3810 \pm 110$

Two portions of black soil with microscopic wood charcoal pieces from Cut 3 at 31 to $32 \mathrm{~cm}$ depth. B-791 consists of charcoal particles ( $>0.2 \mathrm{~mm}$ ) selected by sieving. Cut 3 is $120 \mathrm{~cm}$ long, opened at $\mathrm{N}$ margin of lake which is surrounded by $50 \mathrm{~cm}$ high rim originating from erosion by water level changes during Sub-Atlantic. Soil cut shows 3 wood charcoal horizons (id. by F. Schweingruber, Syst.-Geobot. Inst., Univ. Bern): at 31 to $32 \mathrm{~cm}$ (Abies), from 50 to $71 \mathrm{~cm}$ (Pinus cembra), and at $85 \mathrm{~cm}$ depth. Pollen analysis shows sharp decrease of AP, and 80\% Gramineae. Comment: considerable pollen variations were found in charcoal horizons, indicating woods clearing by fire and subsequent natural reforestation by shrubs (Corylus, Betula) and trees. Date B-794 pub. in description of sec. must be altered.

B-790. Boniger See 3-60, charcoal 
B-792. Boniger See 3-60, soil with charcoal 3120 B.c.

Two portions of black soil with microscopic wood charcoal pieces (Pinus cembra, see comment to B-794, above) from Cut 3 at 50 to $71 \mathrm{~cm}$ depth. Sample B-790 consists of charcoal particles $(>0.2 \mathrm{~mm})$ selected by sieving. Pollen shows reforestation indicators (Pinus increase after Betula and Corylus maximum). Comment: from differences in these pairs of dates (see soil samples 3-30 and 3-60) pure charcoal horizons seem to be ca. 300 yr older than soil with charcoal. Relative proportions of humus and charcoal in soil were not determined. As humic extracts have not been dated, legend "humus" in Profile 3 (Markgraf, 1969, p. 63) must be changed to "soil with charcoal".

B-789. Boniger See 3-69, soil with charcoal

$4830 \pm 100$

Soil with charcoal pieces from Cut 3 at 68 to $71 \mathrm{~cm}$ depth, bottom layer in main charcoal horizon of Sample 3-60 (see above). Comment: sample dates beginning of clearing. Date is coincident within statistics with date of main layer (50 to $71 \mathrm{~cm})(\mathrm{B}-792$, above). Charcoal itself would probably date to ca. 5200 B.P. if relative proportion of humus and charcoal is similar in present sample to previous (3-30 and 3-60, above).

\section{B-786. Boniger See 1-385}

$4740 \pm 100$

Peat with Sphagnum, Drepanocladus, and fungal hyphae, from Core 1 at 370 to $400 \mathrm{~cm}$ depth. Strong increase of Picea and decrease of Abies. Comment: indicators of agriculture appear, showing human influence.

\section{B-793. Boniger See 13-250}

$4870 \pm 100$

Peat with Sphagnum, Drepanocladus, and Cyperaceae rootlets from Core 13, at 220 to $290 \mathrm{~cm}$ depth. Core, $505 \mathrm{~cm}$ long, is from outer $\mathrm{N}$ margin of floating island. Picea increase. Comment: pollen diagram, not described by Markgraf (1969), is similar to that of Core 1 but compressed. General Comment: (Markgraf, 1969) dates indicate human activity (agriculture) and synchronous wood clearings by fire from 5300 to 3700 B.P. Natural fire is excluded for 2 reasons, (1) although possibilities of fire during earlier period with drier climate were greater, no evidence was found in cores from site; (2) cereal pollen, indicators of important agricultural activity, appear in the charcoal horizons. Vegetation changes at 5000 B.P. were greater than known variations in climate (Frenzel, 1966) might cause, and are considered mainly due to human influence. Expansion of Picea was probably related to clearings (V. Markgraf, ms. in prep.) because during reforestation Picea is favored in competition with Abies and Pinus cembra, which grow slower, especially where cattle graze. 


\section{Belalp II series, Valais, Switzerland}

Sec. in bog at Belalp below and SW of Tyndall-Stein $\left(46^{\circ} 23^{\prime} 6^{\prime \prime}\right.$ $\mathrm{N}$ Lat, $7^{\circ} 59^{\prime} 2^{\prime \prime}$ E Long), alt $2290 \mathrm{~m}$, N of Brig-Naters, near Naters, Valais (Wallis), Switzerland. Investigated within the general program (Welten, 1958a) of paleoclimatic studies in region of Aletsch Glacier. Compare Greicheralp and Eggen series (this list), Aletschwald series (Radiocarbon, 1959, v. 1, p. 136), and Bitsch-Naters series (Radiocarbon, 1959, v. 1, p. 136; 1961, v. 3, p. 17-18). Present core (145 cm length), taken with Hiller borer near previous boring (see Belalp series: Radiocarbon, 1961, v. 3, p. 18; 1963, v. 5, p. 305). Coll. 1968 and subm. by M. Welten.

\section{B-981. Belalp II, $55 \mathrm{~cm}$}

$3240 \pm 100$

Hypnaceous and cyperaceous peat from 45 to $65 \mathrm{~cm}$ depth.

\section{B-982. Belalp II, $80 \mathrm{~cm}$}

Hypnaceous and cyperaceous peat from 70 to $90 \mathrm{~cm}$ depth.

\section{B-983. Belalp II, $129 \mathrm{~cm}$}

$6360 \pm 100$

Hypnaceous and cyperaceous peat from 119 to $139 \mathrm{~cm}$ depth.

General Comment: apparent hiatus in sedimentation during Sub-Boreal (approx. between 5000 to 2500 B.P.), considered important for paleoclimatologic evaluation and correlation of diagrams from high alts.

\section{Greicheralp series, Valais, Switzerland}

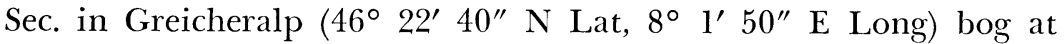
$1915 \mathrm{~m}$ alt, E of Hotel Riederalp, above Mörel, Valais (Wallis), Switzerland. Taken to study vegetational history since Post-Glacial and compare with other profiles in region, esp. Aletschwald series (Radiocarbon, 1959, v. 1, p. 136-137). See also Belalp series (this list) and refs. Pollen anal. by M. Welten (ms. in preparation). $440 \mathrm{~cm}$ core taken with Hiller borer. Coll. 1956 by M. Welten and B. Seddon; subm. 1969 by M. Welten.

\section{B-2002. Greicheralp $92 \mathrm{~cm}$}

$3530 \pm 90$

Cyperaceous peat, strongly humified, from $92 \mathrm{~cm}$ depth.

\section{B-2003. Greicheralp $178 \mathrm{~cm}$}

$3940 \pm 100$

Cyperaceous peat, weakly humified, from $178 \mathrm{~cm}$ depth.

B-2004. Greicheralp $240 \mathrm{~cm}$

$4830 \pm 120$

Hypnaceous peat, from $240 \mathrm{~cm}$ depth. 


\section{B-2005. Greicheralp $340 \mathrm{~cm}$}

Hypnaceous peat, from $340 \mathrm{~cm}$ depth.

\section{B.C.}

B-2006. Greicheralp $413 \mathrm{~cm}$

$5630 \pm 100$

Hypnaceous clayey peat, from $413 \mathrm{~cm}$ depth.

3680 B.C.

\section{Eggen series, Valais, Switzerland}

Sec. in Eggen ( $46^{\circ} 22^{\prime} 13^{\prime \prime} \mathrm{N}$ Lat, $7^{\circ} 59^{\prime} 22^{\prime \prime}$ E Long) $1650 \mathrm{~m}$ alt, $\mathrm{N}$ of Blatten, Valais (Wallis), Switzerland. Bog deposit near moraine sampled to study sedimentation and vegetational history in relation to climatic effects of Aletsch Glacier. Present samples continue previous series (Radiocarbon, 1961, v. 3, p. 18; 1963, v. 5, p. 305; Welten, 1958a). Coll. 1956 and subm. by M. Welten.

\section{B.970. Eggen $190 \mathrm{~cm}$ \\ $3490 \pm 120$ \\ B-971. Eggen $290 \mathrm{~cm}$ \\ 1540 B.C. \\ $5840 \pm 120$ \\ 3890 в.C.}

\section{Hellelen B series, Valais, Switzerland}

Sec. in bog at Hellelen ( $46^{\circ} 17^{\prime} 3^{\prime \prime} \mathrm{N}$ Lat, $7^{\circ} 50^{\prime} \mathrm{E}$ Long), $1510 \mathrm{~m}$ alt, Zeneggen, Valais (Wallis), Switzerland. New boring $840 \mathrm{~cm}$ long, with Hiller borer, at Hellelen-Zeneggen locality (Radiocarbon, 1966, v. 8, p. 25). Description and interpretation of pollen analyses by M. Welten (ms. in preparation). Coll. 1968 and subm. by M. Welten.

\section{B-916. Hellelen $445 \mathrm{~cm}$}

$8780 \pm 120$

Dy from $445 \mathrm{~cm}$ depth (Pre-Boreal).

\section{B-917. Hellelen $455 \mathrm{~cm}$}

6830 B.C.

Dy from $455 \mathrm{~cm}$ depth (Pre-Boreal).

$9430 \pm 120$

7580 в.c.

\section{B-918. Hellelen $521 \mathrm{~cm}$}

$12,310 \pm 150$

Clayey gyttja from $521 \mathrm{~cm}$ depth (beginning of Aller $\phi \mathrm{d}$ ).

\section{Vidy series, Vaud, Switzerland}

Three secs. W of road Vidy-Lausanne, at water-works excavation ( $46^{\circ} 31^{\prime} 18^{\prime \prime} \mathrm{N}$ Lat, $6^{\circ} 35^{\prime} 27^{\prime \prime} \mathrm{E}$ Long), ca. $380 \mathrm{~m}$ alt, in Vidy, Lausanne, Vaud (Waadt), Switzerland. Several borings made in lower deltaic terrace of La Chamberonne $\mathrm{R}$. to determine chronology of sedimentation of Lake of Geneva (Lac Léman) and Vidy terraces. All plant remains id. by collector. Pollen analyses and interpretation by Villaret and Burri (1965). Coll. 1962-63 and subm. by P. Villaret, Inst. Botan. Syst. et Geobot., Univ. Lausanne, Switzerland. 


\section{B-752. Vidy Pb-55}

$12,100 \pm 250$

10,150 в.C.

Wood (Pinus sp., 32 annual rings) from $55 \mathrm{~cm}$ depth in Boring A, in calcareous sand interspersed with several layers of "fumier lacustre" (similar composition to B-751, below) where pollen was analyzed. Pinus dominant. Comment: from pollen and geologic analyses of sediments, considered to date Pre-Boreal (Villaret and Burri, 1965).

\section{B-751. Vidy EMSE 2}

$12,750 \pm 200$

10,810 B.c.

"Fumier lacustre" (abundant twigs, leaves, fruits, and scales of Betula nana, some leaves of Dryas octopetala, leaves and seeds of Juniperus communis ssp. nana, numerous seeds of Caryophyllaceae, fruits of Helianthemum sp., Armeria sp., Onobrychis sp., Thalictrum sp., etc.), from $120 \mathrm{~cm}$ depth in Boring $\mathrm{C}$, in calcareous loam. NAP dominance with $15 \%$ Betula nana pollen. Comment: date corresponds to Older Dryas age in contradiction to expected age (Villaret and Burri, 1965), Oldest Dryas.

\section{B-753. Vidy 02}

$12,400 \pm 200$

Wood (Betula sp., ca. 50 annual rings) from $10.5 \mathrm{~cm}$ depth in core taken near Boring B, in chalky loam. Pollen analysis shows intersection of Pinus and Betula curves. Comment: dates beginning of Aller $\phi d$.

General Comment: dates and pollen analyses show deepest layers belong to Oldest Dryas, indicating sedimentation until Aller $\phi d$ and gap until Sub-Boreal time, attributed to (1) regression of lake, of (2) erosion by lake water during Boreal and Atlantic, later (Sub-Boreal) covered by river sediments. Estimated dates for B-752 and B-753: $1000 \mathrm{yr}$ older than expected from comparison with analyses from site at $35 \mathrm{~km}, \mathrm{La}$ Tourbière (Wegmüller, 1966, p. 29-31, pl. 1; Radiocarbon, 1963, v. 5, p. 307).

\section{B. Austria}

\section{Dobramoos series, Kärnten, Austria}

Sec. in Dobramoos raised bog $\left(46^{\circ} 45^{\prime} 50^{\prime \prime} \mathrm{N}\right.$ Lat, $14^{\circ} 12^{\prime} 30^{\prime \prime}$ E Long), alt $902 \mathrm{~m}$, St. Urban, near Klagenfurt, Kärnten (Carinthia), Austria. Pollenanalytically investigated to study chronology of vegetation in SE Alps. Description and interpretation of analyses pub. by Bortenschlager (1966). Kärnten region was also studied by Schmidt $(1965,1970)$ and Fritz (1967). See also Schwarzer Moor I, Keutschachersee II, and Kohlenmoos series (this list). Two cores taken with Hiller borer. Coll. 1963 by S. Bortenschlager, Inst. für Botan. Syst. und Geobot., Univ. Innsbruck, Austria; subm. by M. Welten. 
B-613. Dobramoos IV-D

$5860 \pm 100$

3910 B.c.

Sphagnum peat from Core IV at 70 to $80 \mathrm{~cm}$ depth. Boring IV $(3 \mathrm{~m}$ long) at ENE border of bog. Oldest Fagus maximum and immigration of Abies. Comment: considered Atlantic time.

\section{B-614. Dobramoos IV-E}

$9000 \pm 120$

Cyperaceous peat from Core IV at 160 to $170 \mathrm{~cm}$ depth. Pinus decrease and NAP increase (Younger Dryas).

\section{B-593. Dobramoos V-180}

$9360 \pm 140$

Cyperaceous peat from Core $\mathrm{V}$ at 180 to (4.20 $\mathrm{m}$ long) ca. $50 \mathrm{~m}$ from Boring IV to to $190 \mathrm{~cm}$ depth. Boring V crease of NAP during minor dip in broad Pinus maximum. Slight in may correspond to Younger Dryas.

\section{B-594. Dobramoos V-230}

$9550 \pm 150$

Cyperaceous peat from Core $\mathrm{V}$ at 230 7600 B.C. Pinus increase. Comment: pollen analysis indicates warm phase thought to be Aller $\phi$ d. Date is $>1000 \mathrm{yr}$ too young if horizon is synchronous with Central Europe sequence.

\section{B-615. Dobramoos IV-F}

$10,820 \pm 150$ 8870 B.c.

Cyperaceous peat from 210 to $220 \mathrm{~cm}$ depth in Boring IV. Strong Pinus pollen increase above marked NAP maximum. Comment: considered Older Dryas.

\section{B-595. Dobramoos V-310}

$12,610 \pm 180$

Cyperaceous peat from 310 to $320 \mathrm{~cm}$ depth in Boring $\mathrm{V}$. dip in broad NAP maximum. Comment: considered to be of $\mathrm{B} \phi l$ ling age.

\section{B-617. Dobramoos V-340}

$12,280 \pm 200$

Cyperaceous peat from 340 to $350 \mathrm{~cm}$ depth in Boring V. NAP broad maximum. Comment: interpreted as Oldest Dryas. This date is not mentioned by Bortenschlager (1966); result not statistically different from Dobramoos V-310.

General Comment: preliminary chronology of vegetational history in Kärnten based on present dates resembles S Central Europe. Main similarity is simultaneous reforestation in both regions by Pinus and Betula during Aller $\phi \mathrm{d}$, although Dobramoos IV-F seems ca. $1000 \mathrm{yr}$ too young (Bortenschlager, 1966). According to Fritz (1967) correlation of Central Europe with E Alps vegetational situation is questionable. 
Recognition of $\mathbf{B} \phi$ lling and Older Dryas is difficult probably due to short length of $\mathbf{B} \phi$ lling and relatively large separation between successive pollen samples. Mean sedimentation rates are $2.7 \mathrm{~cm} / 100 \mathrm{yr}$ (Core IV) and $4 \mathrm{~cm} / 100$ yr (Core V).

\section{Kohlenmoos series, Kärnten, Austria}

Sec. in Kohlenmoos wet raised bog $\left(46^{\circ} 47^{\prime} 0^{\prime \prime} \mathrm{N}\right.$ Lat, $13^{\circ} 34^{\prime} 30^{\prime \prime}$ E Long), at $846 \mathrm{~m}$ alt, between Lake Millstätt and Drau valley, $\mathrm{N}$ of Winkl, Kärnten, Austria. Pollenanalytically investigated by Schmidt $(1965,1970)$ to study vegetational history of outer E Alps; especially in comparison with Schwarzer Moor I and Keutschachersee II series (see below) which have less continental climate than Kohlenmoos. $870 \mathrm{~cm}$ core taken at $\mathrm{N}$ of bog with Hiller borer. Coll. 1964 by H. Schmidt, Stethaimerstr. 15, Salzburg, Austria; subm. by M. Welten.

\section{B-618. Kohlenmoos 1}

$2570 \pm 100$

Sphagnum peat, greatly decomposed, from 200 to $225 \mathrm{~cm}$ depth. Comment: pollen indicates increased human activity; deduced from presence of cereals and sharp decrease of Fagus and Abies.

\section{B-619. Kohlenmoos 2}

$5120 \pm 100$

Cyperaceae peat of varying density, from 395 to $405 \mathrm{~cm}$ depth. Comment: Fagus and Abies horizon with cereals pollen.

General Comment: dates indicate immigration of Fagus, Picea, and Abies earlier than at $\mathrm{N}$ of Alps, maximum of Fagus extension during Atlantic and end of Fagus dominance at beginning of Sub-Boreal. Comparable vegetational development is reported for locality at $15 \mathrm{~km}$, Lengholz (Fritz, 1967) and for Dobramoos (Bortenschlager, 1966, this list, above). Lower sample dates appearance of agriculture as far back as 5120 B.P.

\section{Schwarzer Moor I, Kärnten, Austria}

Sec. in wet raised bog Schwarzer Moor $\left(46^{\circ} 34^{\prime} 30^{\prime \prime} \mathrm{N}\right.$ Lat, $14^{\circ} 23^{\prime}$ $20^{\prime \prime}$ E Long) at $770 \mathrm{~m}$ alt, E of Sattnitz Mts., SE of Klagenfurt, Kärnten (Carinthia), Austria. Pollen profile by Schmidt (1965), to study vegetational history of Sattnitz region. Pollen analyses of related localities in Kärnten reported by Schmidt $(1965,1970)$, Bortenschlager (1966), and Fritz (1967). Core at center of bog, $930 \mathrm{~cm}$ long, taken with Hiller borer. Coll. by H. Schmidt; subm. by M. Welten.

\section{B-620. Schwarzer Moor I-3}

Cyperaceae peat, largely dry and decomposed, from 300 to $325 \mathrm{~cm}$ depth. Brief decrease of Fagus and Abies, NAP increase with indicators of human influence (cereals and Plantago). 
B-621. Schwarzer Moor I-4

$5760 \pm 120$

3810 B.c.

Detritus gyttja, dark brown, from 545 to $555 \mathrm{~cm}$ depth. Abies expansion and decrease of Picea, Fagus, mixed oak forest (Ulmus decrease) and Corylus, due to extensive human influence.

\section{B.622. Schwarzer Moor I-5}

$8785 \pm 150$

Detritus gyttja, dark brown, from 745 to $755 \mathrm{~cm}$ depth. Corylus increase and mixed oak forest maximum. Comment: considered Boreal. At depth 720 to $550 \mathrm{~cm}$ (ca. 8200 to 5800 B.P.) pollen spectrum shows dominance of Corylus and Picea (Atlantic). In younger part of Atlantic, Fagus immigration and expansion; compare similar date, B-597: 6120 \pm 100 в.P., for Keutschachersee (see below).

General Comment: as in Kohlenmoos and Dobramoos series (above), and in Keutschachersee series (below), immigration and extension of Fagus, Picea, and Abies have been dated. Transition from Picea dominance to Fagus increase occurs earlier in more oceanic parts of Kärnten (W) than in those more continental (E) as Kohlenmoos (above) (Schmidt, 1965, 1970). Calculated sedimentation rate is ca. $7.2 \mathrm{~cm} / 100 \mathrm{yr}$.

\section{Keutschachersee II series, Kärnten, Austria}

Sec. in Keutschachermoor bog $\left(46^{\circ} 35^{\prime} 15^{\prime \prime} \mathrm{N}\right.$ Lat, $14^{\circ} 10^{\prime} 30^{\prime \prime} \mathrm{E}$ Long), at $508 \mathrm{~m}$ alt, at $\mathrm{E}$ of lake of Keutschach, $\mathrm{S}$ of Lake Wörth, in W part of Sattnitz Mts., Kärnten (Carinthia), Austria. Vegetational history of outer part of $\mathrm{E}$ Alps was pollen analytically investigated by Schmidt (1965, 1970), Bortenschlager (1966), and Fritz (1967). Core, 940 $\mathrm{cm}$ long, from center of hydrosere on $\mathrm{E}$ of lake, taken with Hiller borer. Coll. 1964 by H. Schmidt; subm. by M. Welten.

\section{B-597. Keutschachersee II, KC VIII-1}

Cyperaceae peat partly with "braunmosses" and Eriophorum leaves, from 200 to $225 \mathrm{~cm}$ depth. Decrease of Picea and increase of Abies, Fagus, and Alnus. Comment: considered end of Atlantic.

\section{B-598. Keutschachersee II, KC VIII-2}

$6910 \pm 100$

Phragmites peat with scattered rests, strongly humified, from 360 to $370 \mathrm{~cm}$ depth. Onset of Picea maximum, decrease of Ulmus and Tilia. Very strong increase of spores of Pteridium and Dryopteris (from ca. $1 \%$ to $>200 \%$ ) and increase of NAP (from $10 \%$ to $40 \%$ ). Comment: considered transition Boreal/Atlantic.

General Comment: dates establish immigration of Fagus, Picea, and Abies earlier than at $\mathrm{N}$ of Alps, maximum extension of Fagus during Atlantic, and end of its dominance at beginning of Sub-Boreal (compare series at Kohlenmoos, Schwarzer Moor, and Dobramoos, this list) (Schmidt, 1965). 
Profile shows detailed Late Glacial development from Oldest Dryas onwards, in clay from 940 to $715 \mathrm{~cm}$ and in chalk from 715 to $520 \mathrm{~cm}$ depth. Subsequent Post-Glacial development shows succession ranging from mixed oak forest to Corylus-Picea phase. Start of Post-Glacial appears delayed ca. 2000 yr compared to Schwarzer Moor (see above). Fern increase, at beginning of Atlantic (Sample KC VIII-2), may be related to forest clearance (Bastin, 1964) but is considered by collector to be due to wetter climate (Schmidt, 1965). Post-Atlantic development is synchronous with Schwarzer Moor (see above).

\section{B-963. Höll, Block IV, Oberösterreich, Austria}

$9040 \pm 130$ 7090 B.c.

Wood from $50 \mathrm{~cm}$ depth in clay of former lake now covered by rockfall material, at Höll ( $47^{\circ} 38^{\prime} \mathrm{N}$ Lat, $14^{\circ} 28^{\prime} \mathrm{E}$ Long), alt ca. $1300 \mathrm{~m}$, near Linzerhaus, Spital am Pyhrn, Totes Gebirge Mts., Kirchdorf a.d. Krems, Oberösterreich, Austria. Coll. 1968 by E. Ebers, D-8121 Haunshofen, Kr. Weilheim, W Germany; subm. by V. Markgraf. Locality in $500 \mathrm{~m}$ long and $90 \mathrm{~m}$ broad widening of Teichl valley at foot of steep walls of Stubwieswipfel Mt. within subalpine Picea forest belt, in former lake covered by rock-fall material with numerous engravings of primitive design (Ebers, 1969). Several cuts were pollen analytically investigated by V. Markgraf to date rock-fall and engravings. Comment: engravings seem to date from several archaeologic times, partially related to paintings of different epochs: e.g., W France megalithic and Bronze and Iron ages (Burgstaller, 1961). At level of present date in pollen digaram, analysis shows transition from Pinus dominance to Picea increase (V. Markgraf, written commun., 1970) which corresponds well to previously dated diagrams from Austria (Fritz, 1967; Bortenschlager, 1966, 1967), where this transition ranges from 10,000 to 9000 B.P. Date agrees with dated diagrams of Seemoos and Dobramoos (this list) but erroneously pub. and interpreted as Aller $\phi \mathrm{d}$ by Ebers (1969).

\section{Seemoos series, Salzburg, Austria}

Sec. in Seemoos raised bog $\left(47^{\circ} 5^{\prime} \mathrm{N}\right.$ Lat, $13^{\circ} 45^{\prime} 30^{\prime \prime} \mathrm{E}$ Long), ca. $1700 \mathrm{~m}$ alt, in pass on Schwarzenberg Plateau, Bezirk Tamsweg in Lungau, Salzburg, Austria. Pollen analytic investigation of forest history and immigration of vegetation in glaciated valleys of E Alps (see Dobramoos, Schwarzer Moor I, Keutschachersee II, and Kohlenmoos series, this list) by Bortenschlager (1967). Human influence since Roman times is indicated. Core $(8.50 \mathrm{~m}$ long) was taken with Hiller borer. Coll. 1963 by S. Bortenschlager; subm. by M. Welten.

\section{B-596. Seemoos I-100}

$880 \pm 100$

Sphagnum peat from 100 to $125 \mathrm{~cm}$ depth with $1 \mathrm{~cm}$ thick charcoal horizon. Increase of NAP and indicators of human activity (cereals, Plantago, and Rumex). Comment: dates transition Older/Younger Sub- 
Atlantic. Variations in Picea and Pinus pollen ratio interpreted as probable clearing by fire for pasture purposes. Age derived from calibration curve (see Introduction) between A.D. 1010 to A.D. 1210.

B-616. Seemoos I-650

$7580 \pm 120$ 5620 B.c.

Cyperaceous peat from 650 to $675 \mathrm{~cm}$ depth. Increase of Picea with simultaneous decrease of Pinus. Comment: interpreted as transition Boreal/Older Atlantic.

General Comment: $\mathrm{C}^{14}$ dates agree with chronology inferred from pollen analyses.

\section{ARCHAEOLOGIC SAMPLES}

\section{A. Switzerland}

\section{Vinelz series, Bern, Switzerland}

Two samples from Vinelz (ca. $47^{\circ} 2^{\prime} \mathrm{N}$ Lat, ca. $7^{\circ} 4^{\prime} \mathrm{E}$ Long), at ca. $440 \mathrm{~m}$ alt, in late Neolithic site on SE branch of lake of Biel (Bieler See), $\mathrm{SE}$ of Erlach, canton Bern, Switzerland. Samples from cultural layer overlain by $1.5 \mathrm{~m}$ of sand, assoc. with potsherds with food remains. Should represent small regional Lüscherz group, perhaps related to Horgen culture. Chronologic setting not completely determined; expected younger than Cortaillod culture (see Seeberg Burgäschisee-Süd series: Radiocarbon, 1959, v. 1, p. 140-142; 1961, v. 3, p. 23-24) and older than Schnurkeramik culture (see Auvernier series: Radiocarbon, 1967, v. 9, p. 30; (Strahm, 1965-1966, 1970). Coll. 1960 and subm. by C. Strahm, Inst. für Ur- und Frühgeschichte, Univ. Freiburg, W Germany.

\section{B.778. Vinelz 1}

$4170 \pm 250$

Wood charcoal Comment: date, derived from calibration of scale with tree rings (see Introduction), is 3400 B.c. to 2600 B.c.

\section{B.779. Vinelz 2}

\section{Seeds, nutshells, and cham} curve, is 3380 B.C. to 2980 B.C.

General Comment: both dates are coincident and agree with expectations.

\section{La Baume d'Ogens series, Vaud, Switzerland}

Site $1 \mathrm{~km} \mathrm{E}$ of Ogens ( $46^{\circ} 43^{\prime} \mathrm{N}$ Lat, $6^{\circ} 44^{\prime} \mathrm{E}$ Long), at $672.90 \mathrm{~m}$ alt, in dist. of Moudon, ca. $13 \mathrm{~km}$ SE of Yverdon, Vaud (Waadt), Switzerland. Discovered 1955 (Egloff, 1965; Wyss, 1968) in a fault S oriented facing Augine R., is 1st reported Mesolithic rock shelter from Molasse formation in Jura; contains 6 Epipaleolithic hunter-gatherers occupation levels alternating with sand layers. Assoc. finds are largely similar to those of lower levels in Birsmatten-Basisgrotte (Bandi, 1964; Radiocarbon, 1961, v. 3, p. 23). Stone artifacts (sieved out with mesh $2 \mathrm{~mm}$ ) correspond 
to microlithic types made out of silex, quartzite, radiolarite, and rockcrystal, from nearby moraine. Finds include triangles, scrapers, backed bladelets, and punches. Artifacts of bone are smoothers, fragments of boar tusks, and perforated deer grandles. Similar lithic industry later discovered at Abri de la Cure in Baulmes (Egloff, 1966-67, 1967). Fauna remains, id. by P. Strinati (mainly Cervus elaphus, Capreolus capreolus, Sus scrofa, Meles meles, Vulpes vulpes, and Martes). No pollen has been conserved, but in charcoal layer are found macroscopic plant remains, id. by M. Villaret, Mus. Bot. Lausanne (Quercus, Corylus avellana, Sorbus torminalis, Fraxinus, scarce Pinus, and Cornus sanguinea); considered to represent younger part of Boreal (M. Villaret, 1970, written commun.).

Stratigraphic excavation 1964-66 and coll. 1964-65 by M. Egloff, Mus. Cantonal Archéol., Neuchâtel, Switzerland; subm. by R. Kasser, Univ. of Geneva, Switzerland.

B-764. La Baume d'Ogens 1

$8530 \pm 100$

6580 B.c.

Charred wood and nutshells from Layer $4 \mathrm{~b}$ (penultimate occupation level) at $+25 \mathrm{~cm}$ from ref. level.

B.765. La Baume d'Ogens 2

$8735 \pm 150$ 6785 B.c.

Small pieces of charcoal from Layer 13, oldest occupation level at $-50 \mathrm{~cm}$ from ref. level.

General Comment: dates agree with previous radiocarbon dates for similar archaeologic material (Radiocarbon, 1961, v. 3, p. 23; Gfeller, 1964) but seem somewhat older than Younger Boreal (compare: Zoller, 1968, p. 29) suggested by macrofossils analyses above.

$$
\text { B. Egypt }
$$

\section{Kellia series, Beheira, Egypt}

Four samples from Qouçoûr' Isâ Sud I, complex ca. $75 \mathrm{~m} \times 70 \mathrm{~m}$, with $>100$ chambers and 2 basilicas, in Kellia $\left(30^{\circ} 45^{\prime} \mathrm{N}\right.$ Lat, $30^{\circ} 22^{\prime} \mathrm{E}$ Long), coptic monasteries site at $\mathrm{E}$ border of Libyan desert, some $\mathrm{km}$ from Nile Delta in Marquaz, Dilingat, prov. of Beheira, Egypt; was rediscovered in 1964. More than 1200 constructions with walls made of unburnt bricks covered with mortar have been found in area $(12 \mathrm{~km}$ $\times 3.5 \mathrm{~km}$ ). Most common type of monastery has yard (average $20 \mathrm{~m} \times$ $30 \mathrm{~m}$ ) with water well, garden, and basins, limited by rectangular wall. At W, cells, prayer rooms, and kitchen. Assoc. finds consist of abundant ceramics, numerous wall decorations and inscriptions, and some coins; sculpture rarely present. Organic rests consist of bones and wood charcoal. Main purpose of research was to date ceramics and glass-ware, and study architectural evolution of site; 9 other dates are known from same site (Hv-unpub., M. A. Geyh, 1969, written commun.) and are discussed below. Site described by Kasser (1967) and Daumas and Guillaumont (1969). Subm. by D. Weidmann, Fouilles Coptes, Univ. Geneva, Switzerland. 


\section{B-802. Qouçour 'Isâ Sud I, Pit 1, Layer 3}

Wood charcoal from Layer 3, ca. $3.50 \mathrm{~m}$ depth in Refuse Pit 1 assoc. with ceramics, glass-ware and kitchen trash. Constantine coin (A.D. 379 to 395) gives expected date for sample. Coll. 1966 by R. Kasser, Fac. of Letters, Univ. Geneva, Switzerland. Comment: date derived from calibration curve (see Introduction) is 140 B.c. to A.D. 100, considered too old by collector, who attributes discrepancy to fossil resin or bitumen in sample. Deeper Layer 10 (see below) was dated somewhat younger.

\section{B-803. Qouçour 'Isâ Sud I, Pit 1, Layer 10}

$1650 \pm 100$

Wood charcoal from Layer 3, in Pit 1; ca. $4.50 \mathrm{~m}$ depth. Expected contemporary with dated sample of charcoal at $4 \mathrm{~m}$ depth in Pit 2 (Hv2388: $1585 \pm 60$ B.P., $=$ A.D. 400 to A.D. 510 after conversion to calendar yr), and not older than A.D. 379 (see comment, above, to Layer 3). Coll. 1966 by R. Kasser. Comment: corresponding date derived from calibration curve( see Introduction) is A.D. 180 to A.D. 450, agrees with expectations.

\section{B-804. Qouçour 'Isâ Sud I, Tomb 5}

$1310 \pm 120$

Human bone at $2 \mathrm{~m}$ depth in cemetery with ca. 200 tombs. Skeletons are found buried in sand without any dated object. Cemetery believed in use until ca. A.D. 700 above ruins of part of abandoned monastery (from date of S.50, below). Coll. 1966 by D. Weidmann. Comment: date corrected for secular variations in $\mathrm{C}^{14}$ (see Introduction) is A.D. 600 to A.D. 840, agrees with expectations. Correction for isotopic fractionation would make age from 90 to $270 \mathrm{yr}$ older depending on $\mathrm{C}^{13} / \mathrm{C}^{12}$ ratio (Radiocarbon, 1967, v. 9, p. 114, 116, 117; 1969, v. 11, p. 351).

\section{B-988. Qouçour 'Isâ Sud I, S.50}

$1530 \pm 100$

Large wood charcoal pieces from ca. $1 \mathrm{~m}$ depth in kitchen, assoc. with abundant ceramics (pots, amphorae). Date expected not older than A.D. 610 , based on assoc. with Heraclius coin. Coll. 1967 by D. Weidmann. Comment: corrected $\mathrm{C}^{14}$ date (see Introduction) is A.D. 310 to A.D. 580. Another charcoal sample from same kitchen was dated (Hv-2390): 1295 \pm 75 B.P. (converted to A.D. 630 to A.D. 820 by use of calibration curve). Coin and present radiocarbon date do not disagree if a $2 \sigma$ interval is taken. Preferred explanation is that wood was re-used from older churches, as suggested by traces in charcoal pieces.

General Comment: dates 2 phases of occupation: (1) construction of monastery with large trash pits containing abundant and typical pottery, glass-ware, and refuse (bones, fish-bones, vegetables, etc.) dated to lst half of 5 th century A.D. by Samples B-803 (this series) and Hv-2388 (charcoal in Pit 2): $1585 \pm 60$ B.P., Hv-2619 (charcoal at base of tower, S.64): 
$1565 \pm 55$ в.P., B-802 (this list) and Hv-2617 (fish-bone in amphora, S.65): $3305 \pm 245$ B.P., should be contemporary according to assocs.; (2) last occupation of Qouçoûr 'Isâ Sud I and perhaps whole site Kellia. Dated in kitchen ovens of 3 different constructions between end of 7 th and beginning of 8th centuries A.D., by samples B-988 (this series) and Hv-2390: $1295 \pm 75$ в.P. (charcoal in kitchen, S.50) Hv-2389: $1310 \pm 45$ в.P. (charcoal in kitchen from Building 6), and Hv-2621: $1335 \pm 60$ в.P. (charcoal from Kitchen SO in Building 366). Most recent date from inscription in Kellia is A.D. 739; arabic sources comment that site was in ruins and almost uninhabited in 9th century A.D., thus agrees with Hv-2622: $1010 \pm 50$ B.P. dating charcoal in ruins (Room B, Building 366) assoc. with atypical ceramics and arabic (moslem) coins younger than A.D. 644 . Standard deviation is too large for other 2 samples (Hv-2618: $1685 \pm$ 265 in ashes and charcoal from Kitchen S.82, and Hv-2620: $1810 \pm 255$ in ashes and charcoal from Site S.48) which could provide information about development during middle occupation period.

\section{Alaska}

\section{Kodiak Island series, Alaska, U.S.A.}

Two samples from 2 sites in Anton Larsen Bay ( $57^{\circ} 52^{\prime} \mathrm{N}$ Lat, $152^{\circ}$ $40^{\prime}$ W Long), arm of Kizhuyak Bay, at NE of Kodiak I., Alaska. Sites are ca. $500 \mathrm{~m}$ from each other. First sondage in 1959 with subsequent exposure allowed study of artifacts by Clark (1964). Sites provide information about change of Kachemak tradition to Eskimo Koniag phase (Clark, 1964, 1966, 1968, 1970). Present dates belong to general Kodiak I. series (Radiocarbon, 1966, v. 8, p. 367-369). Coll. 1964 to 1966 by D. W. Clark, Dept. Anthropol., Univ. Wisconsin, U.S.A.; subm. by H. Müller-Beck.

\section{B-835. Crag Point, Site 241}

$1100 \pm 100$

Charred material, probably sea mammal oil, scraped from potsherds in upper part of site. Expected to date end of site occupation with unsuccessful attempt to introduce pottery into area. Sherds considered not intrusive from re-occupations. Comment: date derived from $\mathrm{C}^{14}$ calibration curve (see Introduction) is A.D. 770 to A.D. 1050, agrees with expectation to date end of occupation and early changes to Eskimo Koniag phase between ca. A.D. 1050 and 1100 . Deeper sample of same site gave reasonable, older date, P-1057 (Radiocarbon, 1966, v. 8, p. 369): $2033 \pm 52$ в.P.

\section{B-836. Kizhuyak, Site 240}

$600 \pm 100$

Small charcoal particles from lower midden layer, $3 \mathrm{~m}$ thick. Expected to provide early date for Koniag phase, and to differ 100 to 200 yr from Crag Point sample (see above). Comment: date derived from calibration curve (see Introduction), is A.D. 1270 to A.D. 1420, thus agrees with expectation. This is oldest of 6 charcoal dates (Radiocarbon, 1966, v. 8, p. 368) from Koniag phase. 
REFERENCES

Bandi, H-G. (ed.), 1964, Birsmatten-Basisgrotte, eine mittelsteinzeitliche Fundstelle im unteren Birstal: Acta Bernensia, v. 1, p. 3-271.

Bastin, Bruno, 1964, Recherches sur les relations entre la végétation actuclle et le spectre pollinique récent dans le Forêt de Soignes (Belgique): Agricultura, 2nd ser., v. 12 , p. $341-373$.

Beug, H.-J., 1964, Untersuchungen zur spät- und postglazialen Vegetationsgeschichte im Gardaseegebiet unter besonderer Berücksichtigung der mediterranen Arten: Flora, v. 154, p. 401-441.

Bortenschlager, Sigmar, 1966, Pollenanalytische Untersuchung des Dobramoores in Kärnten: Carinthia II, v. 156 , p. 59-74.

1967, Pollenanalytische Untersuchung des Seemooses im Lungau (Salzburg): Zool.- Bot. Gesell. in Wien Verh., v. 107, p. 57-74.

Burgstaller, Ernst, 1961, Felsbilder und -inschriften im Toten Gebirge in Oberösterreich: Oberösterreich. Heimatblätter, v. 2/3, p. 57-101.

Clark, D. W., 1964, Incised figurine tablets from Kodiak, Alaska: Arctic Anthropol., v. 2 , no. 1 .

1966, Perspectives in the prehistory of Kodiak Island, Alaska: Am. Antiquity, v. 31 , p. $358-371$.

1968, Koniag prehistory: M.S. dissert., Univ. Wisconsin.

1970, The late Kachemak tradition at Three Saints and Crag Point, Kodiak Island, Alaska: Arctic Anthropol., in press.

Daumas, Francois and Guillaumont, Antoine (eds.), 1969, Kellia I, Kôm 219, in: Fouilles de l'Inst. Français d'Archéol. Orientale, Impr. Inst. Français d'Archéol. Orient., Cairo, 1969.

Ebers, Edith, 1969, Das Felsbildergebiet im der Höll am Warscheneck und seine nacheiszeitliche Geschichte: Oberösterreich. Heimatblätter, v. 23, p. 72-74.

Egloff, Michel, 1965, La Baume d'Ogens, gisement epipaléolithique du plateau Vaudois; note préliminaire: Schweizer. Gesell. Urgeschichte Jahrb., v. 52, p. 59-66.

_ 1966-67, Les gisements préhistoriques de Baulmes (Vaud): Schweizer. Gesell. Ur- und Frühgeschichte Jahrb., v. 53, p. 7-13.

1967, Huit niveaux archéologiques à l'Abri de la Cure (Baulmes, canton de Vaud): Ur-Schweiz/La Suisse Primitive, v. 31, p. 53-64, Basle.

Frenzel, Burkhardt, 1966, Climatic change in the Atlantic/Sub-Boreal transition on the Northern Hemisphere; botanical evidence, in: World Climate from 8000 to 0 B.C., Internatl. Symposium on world climate, Royal Meteorol, Soc Proc, p. 99-123.

Fritz, Adolf, 1967, Beitrag zur spät- und postglazialen Pollen-stratigraphie und Vegetationsgeschichte Kärntens: Carinthia II, v. 77, p. 5-37.

Gfeller, Christian, 1964, Alterbestimmung der Fundhorizonte nach der $\mathrm{C}^{14}$-Methode, in: Birsmatten-Basisgrotte, eine mittelsteinzeitliche Fundstelle im unteren Birstal: Acta Bernensia, v. 1, p. 88-91.

Gfeller. C., and Oeschger, H., 1963, Bern radiocarbon dates III: Radiocarbon, v. 5, p. $305-311$.

Gfeller, C., Oeschger, H., Schwarz, U., 1961, Bern radiocarbon dates II: Radiocarbon, v. 3 , p. $15-25$

Kasser, Rodolphe (ed.), 1967, in: Recherches suisses d'archéologie copte: Georg, Lib. de l'Univ. Geneva, v. 1.

Lang, G., 1952, Zur späteiszeitlichen Vegetations- und Florengeschichte Südwestdeutschlands: Flora, v. 139, p. 243-294.

Lerman, J. C., 1970, Discussions, in: Radiocarbon variations and absolute chronology, 12th Nobel Symposium, Proc., I. U. Olsson (ed.), Stockholm, Almqvist; New York, Wiley.

Markgraf, Vera, 1969, Moorkundliche und vegetationsgeschichtliche Untersuchungen an einem Moor an der Waldgrenze im Wallis: Bot. Jahrb., v. 89, p. 1-63.

Nilsson, Tage, 1964, Standard-Pollendiagramme und $\mathbf{C}^{14}$ Datierungen aus dem Ager $\varnothing \mathrm{ds}-$ mosse im mittleren Schonen: Lunds Univ. Årssk., N.F. Afd. 2, v. 59, p. 1-52.

Oeschger, H. and Riesen, T., 1965, Bern radiocarbon dates IV: Radiocarbon, v. 7, p. 1-9. 1966, Bern radiocarbon dates V: Radiocarbon, v. 8, p. 22-26.

1967, Bern radiocarbon dates VI: Radiocarbon, v. 9, p . 28-34.

Oeschger, H., Schwarz, U., Gfeller, C., 1959, Bern radiocarbon dates I: Am. Jour. Sci. Radiocarbon Supp., v. 1, p. 133-143.

Olsson, I. U., El-Gammal, S., and Göksu, Y., 1969, Uppsala natural radiocarbon measurements IX: Radiocarbon, v. 11, p. 515-544. 
Schmidt, Helmut, 1965, Palynologische Untersuchungen an drei Mooren in Kärnten (mit pollen- und sporenmorphologischem Anhang): M.S. dissert., Univ. Innsbruck, Austria.

\section{Carinthia II, in press.}

Schweizerische Gesellschaft für Ur- und Frühgeschichte, 1968-1970, Ur- und Frühgeschichtliche Archäologie der Schweiz, v. 1, Die Ältere und Mittlere Steinzeit, v. 2, Die Jüngere Steinzeit, Basle, Switzerland.

Staub, Walther, 1927, Morphologische Beobachtungen in den Visper Tälern: Gesell. Erdkunde Zeitschr., Berlin, v. 1927, no. 4, p. 216-220.

Strahm, Christian, 1965-1966, Ausgrabungen in Vinelz 1960: Bernischen Historischen Mus., Jahrb, Bern, v. 45-46, p. 283-320.

1970, Die späten Kulturen, in: Ur- und Frühgeschichtliche Archäologie der Schweiz, v. 2, Die jüngere Steinzeit: Schweizer. Gesell. Ur- und Frühgeschichte, Basle, p. 96-116.

Stuckenrath, R., Jr., Coe, W. R., and Ralph, E. K., 1966, University of Pennsylvania radiocarbon dates IX: Radiocarbon, v. 8, p. 348-385.

Suess, H. E., 1970, Bristlecone pine calibration of the radiocarbon time scale 5300 B.c. to the present, in: Radiocarbon variations and absolute chronology, 12th Nobel Symposium Proc., I. U. Olsson (ed.), Stockholm, Almqvist, New York, Wiley, in press.

Villaret, Pierre and Burri, Marcel, 1965, Les découvertes palynologiques de Vidy et leur signification pour l'histoire du Lac Léman: Soc. Vaudoise Sci. Natur. Bull., v. 69 , fasc. 1 , p. $1-19$

Vogel, J. C. and Lerman, J. C., 1969, Groningen radiocarbon dates VIII: Radiocarbon, v. 11, p. 351-390.

Vogel, J. C. and Waterbolk, H. T., 1967, Groningen radiocarbon dates VII: Radiocarbon, v. 9, p. 107-155.

Wegmüller, Samuel, 1966, Über die spät- und postglaziale Vegetationsgeschichte des südwestlichen Jura: Beitr. geobot. Landesaufn. Schweiz, v. 48, p. 1-144.

Welten, Max, 1958a, Die spät- und postglaziale Vegetationsentwicklung der Berner Alpen und des Walliser Haupttales: Veröff. Geobot. Inst. Rübel, Zürich, v. 34, p. $150-158$

1958b, Pollenanalytische Untersuchung alpiner Bodenprofile; historische Entwicklung des Bodens und säkulare Sukzession der örtlichen Pflanzengesellschaften: Veröff. Geobot. Inst. Rübel, v. 33, p. 253-274.

Wyss, René, 1968, Das Mesolithikum, in: Ur- und Frühgeschichtliche Archäologie der Schweiz, v. 1, Die ältere und mittlere Steinzeit: Schweizer. Gesell. Ur- und Frühgeschichte, Basle, p. 123-144.

Zoller, Heinrich, 1960, Pollenanalytische Untersuchungen zur Vegetationsgeschichte der insubrischen Schweiz: Denkschr. Schweiz. Naturf. Gesell., v. 83, no. 2, p. i-vi $+45-156$.

1968, Die Vegetation vom ausgehenden Miozän bis ins Holozän, in: Urund frügeschichtliche Archäologie der Schweiz, v. 1, Die Ältere und Mittlere Steinzeit: Schweizer. Gesell. Ur- und Frühgeschichte, Basle, p. 27-42.

Zoller, H. and Kleiber, H., 1967, Über die postglaziale Einwanderung und Ausbreitung der Rotbuche (Fagus silvatica L.) am südlichen Alpenrand: Bauhinia, v. 3, p. $255-264$. 